\title{
The Notion of Leadership and Civic Engagement in Adolescents
}

\author{
Denise D'Auria-Tardeli \\ Graduate Education Program, Universidade Metodista de São Paulo, São Paulo, Brazil \\ Email: denisetardeli@gmail.com
}

How to cite this paper: D'Auria-Tardeli, D. (2021) The Notion of Leadership and Civic Engagement in Adolescents. Open Access Library Journal, 8: e7646. https://doi.org/10.4236/oalib.1107646

Received: June 15, 2021

Accepted: July 12, 2021

Published: July 15, 2021

Copyright (C) 2021 by author(s) and Open Access Library Inc.

This work is licensed under the Creative Commons Attribution International License (CC BY 4.0).

http://creativecommons.org/licenses/by/4.0/

\begin{abstract}
This paper aims to discuss the awakening of civility in adolescents through the conception they have about political leadership. It proposes to consider how identity relates to civic actions, analyzing what young people think of their political leaders and the notion of civism. Our hypothesis is that the idea of ethical/non-ethical leadership projection allows the identification with moral values (dignity and respect) and material values (power). Theoretically, our discussion is supported by studies on psychology and moral education. Data were collected from 219 individuals, boys and girls, aged 10 to 13 years, instructed in private schools, from Baixada Santista, state of São Paulo, Brazil. A questionnaire was prepared and applied to participants who were asked about television and movie characters they found most interesting. Based on their choices, it was concluded that attention to civility is strictly related to education for ethics.
\end{abstract}

\section{Subject Areas}

Psychology, Education

\section{Keywords}

Leadership, Civism, Identity, Adolescence

\section{Introduction}

Except in primitive societies, where power used to be distributed in the community through relatively rule-based customs, in all known human societies, power and charisma have always been present. Why have there always been people capable of playing the role of guides, of leading others? What lies beneath leadership? Since pristine times, leadership, as a phenomenon, has always fascinated human beings due to its peculiar essence. However, at the same time, leadership 
has ever since been a difficult issue to evaluate and a difficult phenomenon to measure. For centuries, such status has been corroborated by discussions about leadership often in the form of mere descriptions of historical facts and stories about heroes rather than formal investigations and research on the topic.

For political sciences, leadership is not an easily identifiable phenomenon either. It has no defined locus-it is neither parliament nor the seat of government-it is, however, a socially constructed concept, difficult to be conceived with precision. Given that difficulty, leadership has been used in different manners to refer to so many distinct situations that it is practically impossible not to come up with a partial or inaccurate definition.

In this paper though, leadership will be considered as one of the basic elements of political science, but it must be emphasized that such a concept is not found in most social sciences guidebooks, where it is treated unsystematically, if not avoided by political sciences proper.

And political leadership is recognized as an essentially interactive phenomenon and result from social relationships; to some extent, it means the ability that some people have to persuade others in terms of belief and behavior. The political leader is the prophet, the warrior hero or the great demagogue, who, through his/her revelations, actions or decisions; respectively, is obeyed irrespective of laws or traditions, is respected simply by the power granted to him based on belief, miracles, success in battles or prosperity of his/her subjects. The concept of charisma is, however, very broad, but, naturally, it is associated with personal magnetism, to the ability someone has to persuade and attract others, inspiring reverence, fervor or emotional dependence [1].

In that sense, our discussion intends to establish a relationship between the concept of leadership and the concept of citizenship, since its origin refers to discussions of political philosophy and to the idea of government and rulers. Where those ideas converge, there lies education as a guarantee for the good functioning of government, considering Aristotle's discussions [2] about the good ruler, or the good citizen.

Like the concept of leadership, the meaning of citizenship is essentially controversial; however, this paper intends to discuss the awakening of youth civic engagement in present-day society, seeking to undo the controversy surrounding the idea that good citizenship is an integral part of what democracy in fact is. Our study seeks to demonstrate that citizenship must be understood as political identity, regardless of different points of view.

Explaining better, etymologically, civism derives from the Latin word civis, "citizen". Accordingly, civism embraces the set of qualities allowing citizens to live in communities respecting norms of peaceful coexistence, accepting rules of democracy and of basic rights, that is, of constitutional values. Civic refers to the typical behavior of a citizen, and civic learning is related to the acquisition of knowledge, abilities and predisposition necessary for good citizenship.

The concept of both civism and public virtues [3] has gained importance in 
the past years due to the increasing need for discussing the role the citizen must play in liberal democracies. Liberalism, in its broader sense, imposed especially in the Western world, is the political regime, which includes the recognition not only of civil rights but also of social rights, such as education or health protection.

The relationship between citizenship and political identity is naturally established since there is no neutrality in educating for citizenship. Internal aspects, such as world view, and external influences participate in that relationship. For that reason, we sought to understand the ideas preteens have about leadership, identifying the projections they make about civic engagement.

There are many definitions of civic engagement. For the purposes of this paper we use Ehrlich's [4] definition and according to him, civic engagement is working to make a difference in the civic life of our communities and developing the combinations of knowledge, skills, values, and motivations to make the difference. It means promoting the quality of life in a community through both political and non-political processes (p. vi).

The importance placed on the value of civism today represents a development of virtue ethics, as conceived by Aristotle [2]. For the Greek philosopher, virtues were the core of both ethics and politics. In century IV B.C., being a good person meant being a good citizen. Only free men could be good citizens since they were able to exceptionally dedicate themselves to public life. Aristotle [2] himself defines the human being as "a political animal", whose one and only purpose is to be a good citizen in the polis.

\section{Methodology}

Our research consists of a prevalence study and its main objective is to discuss the awakening of civic engagement in preteens in present-day society through the conception they have of political leadership.

A critical point that our study intends to observe is that preteens must understand the nature of their rulers, how they can participate socially and the importance of their participation. Education for civism, like other fields of knowledge, should be among top educational priorities. However, topics about civic education do not receive the proper attention from educational institutions and the knowledge children and adolescents have of civism or of government issues are very limited.

Encouraging a climate of open dialogue about such issues, about teachers' behavior and about the school atmosphere is important and equally crucial for constructing education for civism. Education must reject simplistic definitions, leading students to understand civic engagement as a type of formal or electoral policy that involves public offices, political meetings or electoral offices, without necessarily joining a political party. Although those are actual civic activities, they represent just one possible expression of engagement. As an additional objective, our research intends to call attention to such issues; thus, our main ob- 
jective has the following implications:

1) Firstly, our study aims at verifying what preteens believe political leadership means.

2) Accordingly, our focus is on identifying the projections preteens make of their political leader, symbolized in anti-hero characters.

3) At last, our study discusses moral values of civism and of citizenship from the perspective of preteens who have witnessed both the world and national political scene in the last three years.

This prevalence study was conducted with 219 preteens, boys and girls, at ages 10 to 13 years, who have studied in private schools, from the region of Baixada Santista, state of São Paulo, Brazil. The choice of this age group is justified by its very peculiar characteristic, which, according to Piaget [5], considering a cognitive-evolutionary approach, is very representative in terms of moral civic development. This age range corresponds to the moment of transition from heteronomous morality - which according to Piaget [5], is characterized by moral realism, a consequence of operational egocentrism, leading the child to consider the contents of consciousness as if they were material-to autonomous morality, which emerges from the individual himself/herself as a set of principles of justice, based on equality, mutual respect and cooperation relations.

This age group presents morality of exchange, that is, the individual has his/her own interests that may be conflicting with the interests of others. By realizing that each individual has his/her own interests, preteens are led to overcome the absolutism and moral realism of the previous stage, making them adopt a hedonistic and relativistic moral perspective, according to which, the best way to resolve conflicts is through direct and concrete instrumental exchanges dealing with the interests of each individual in a strictly equal manner. Therefore, this transitional stage, also explained by Kohlberg [6], seemed quite appropriate to evaluate what the participants of our study think about the world and national political scene. Based on that, we can discuss the values relative to leadership and citizenship by assessing what preteens know about their political institutions and politicians in general.

Our study will not focus on comparisons between school contexts or productivity, but on the idea that preteens do attend school, and gain experience by doing so. To detect the idea that preteens have of leadership, the following questionnaire was prepared:

Character Quiz: the questionnaire, prepared for this specific study, aims at identifying aspects and characteristics of television and movie villains that arouse interest in children and adolescents.

Based on fictional characters, it is believed that the symbolic element contained in the identities of the villains can provide the direct projection of adolescents. In addition, the films are attractive to young audiences who strive to see certain characters react as anyone in the same situation would.

Ten characters were selected from present-day television shows and movies, 
except Disney characters. They have been excluded since we believe the Disney Family villains do not cause cognitive conflict or doubts, since they are absolutely defined within stereotypes of good and evil, in a Manichaean fashion, leaving no room for nuance. The chosen characters were:

- Darth Vader from Star Wars [7].

- Apocalypse from $X$-Men [8].

- Thanos from Guardians of the Galaxy and Avengers. Infinity War [9] [10].

- Loki from The Avengers [11].

- Lex Luther from Batman v Superman: dawn of justice [12].

- Joker from The Dark Knight [13].

- Negan from The Walking Dead [14].

- Rumpelstiltiskin from Once upon a time [15].

- Ramsey Bolton from Game of Thrones [16].

- Voldemort from Harry Potter saga [17] [18].

This instrument was specially organized for this study. The questionnaire consisted of one question only, namely: "Out of the characters listed below, which do you find most interesting? Justify your answer". The question serves two purposes: one that is inherently investigative and another that is reflexive/educational, since it leads to self-orientation, allowing respondents to reflect on what is most meaningful to them. Thus, after respondents completed the questionnaire, we tried to establish most significant topics of response to think about the various possibilities of analysis, starting at the various possibilities of projections and conceptions that preteens have about the binomial political leader/civism, and how they relate to the construction process of moral personality.

Content analysis is therefore supported by reflexive and imaginative data, which we can evaluate from the respondents' own conceptions according to their personal development, interpersonal relationships, social activities and/or policies, the relationship with nature, as well as philosophical, creative and ethical manifestations.

With the collection of these data, it was verified what preteens highly regard moral and material values, that the notion of leadership is implicit in their responses and how it relates to future purposes. The treatment of the collected data was done simply, from the general computation of the choices, presented in percentage indexes, showing the three most chosen characters to be discussed in the profile analysis. Our qualitative analyses do not compare data between genders, since no significant difference between boys' and girls' responses was observed.

After that contextualization, our research question is presented: What do preteens think of political leaderships of today's society and how do they develop the concept of civility?

As a result, three hypotheses are proposed which will be confirmed in the conclusions:

1) There is an ethical/non-ethical projection of political leadership that allows 
identifying with moral values (dignity and respect) and with material values (power and goods) that is triggered from interactive media.

2) The notion of civility is manifested by symbolic projection to establish social insertion that evinces citizenship, the common good, or rapid enrichment, and rise to power.

3) Charismatic identification with a person due to his/her supernatural attributes, magical faculties, exaggerated heroism, intellectual or oral power that generates a personal devotion to the warrior hero or to the great demagogue(television or movie villains)

\section{Results}

The word "leadership" derives from the verb "to lead", from Old English, lithan, which meant "to go," "to go ahead," and from Old High German, lidan, which meant "to go" [19].

The origin of leadership is very likely to have come from the figure of the warrior in primitive communities. Those warriors used to be extremely independent as they were always out on expeditions, looking for provisions to live on, or abducting foreign women, for example. Their lifestyle made them break family bonds; otherwise, they would have to rely on other people from their tribe to survive. That is the first figure of the free and independent man ever known: a combination of victory and conquest, endowed with social recognition, protection, defense and security [20].

Now, we draw our attention to how leadership can be understood today. Leadership, in its broader sense, is perceived as a purely personal attribute, which relates to the traits of character that allow the leader to exert certain influence on others. Political leadership, for example, is recognized as an essentially interactive phenomenon and result from social relationships; to some extent, it means the ability that some people have to persuade others in terms of belief and behavior. Definitions of leadership abound due to people's different objectives, to specific contexts, to the motivations of a leader, to the expectations of his/her followers, among others.

In view of that, leaders can be considered those who, within a group, detect their position of power as influencing their strategic decisions, and actively exercise that power, which is legitimized by the group.

Table 1 below shows the results of our survey in which 219 preteens aged 10 to 13 were asked about the television and movie character they found most interesting.

\section{Discussion}

The characters listed in the questionnaire, used in our analysis, were created for movies of the last two centuries, which we consider post-classical productions, that according to González Requena [21], rather than provoking distancing from the audience, movie directors use all possible resources to establish total empathy, 
Table 1. Data collected from questionnaire survey. The characters' choices appear below in the table, in simple percentage data.

\begin{tabular}{cc}
\hline Question: Out of the characters listed below, which do you find most interesting? & \\
\hline None & $0.46 \%$ \\
Darth Vader (Star Wars) & $7.16 \%$ \\
Apocalypse (X-Men) & $0.91 \%$ \\
Thanos (Guardians of the Galaxy) & $23.16 \%$ \\
Loki (The Avengers) & $8.14 \%$ \\
Lex Luthor (Superman) & $2.54 \%$ \\
Joker (Batman) & $25.48 \%$ \\
Negan (The Walking Dead) & $7.67 \%$ \\
Rumpelstiltiskin (Once upon a time) & $9.43 \%$ \\
Ramsey Bolton (Game of Thrones) & $0.45 \%$ \\
Voldemort (Harry Potter) & $14.51 \%$ \\
TOTAL & $100 \%$ \\
\hline
\end{tabular}

Source: from the author.

making spectators experience an intense emotional discharge. The idea is that the audience viscerally takes part in the story and feels the characters' emotions. The characters selected for our analysis allow the audience to connect with them on the emotional level, not only because they are heroes or superheroes, but because they were created to cause a deep and meaningful interaction with viewers.

We can say that in movies considered post-classical, the structure of the classical narrative is reverted, that is, the emotional force and suspense are achieved by what is being deconstructed. The audience is caught by the inversion of the structure of symbolic narrative, which is modified and recreated. According to Sanchez Casarrubios [22], that is a process of construction and reconstruction.

Certainly, the figure of the villain is vital in post-classical narratives, and the plot is constructed around him/her: false heroes who become villains, villains who behave as protagonists, intense characterization of the evil figure, among other situations. The villain is in today's movies or television series the key character for the protagonist development, becoming in some stories even more important than the hero himself/herself. This is the case of many of the characters listed above, Voldemort, Darth Vader, Negan and even Joker (highest ranking among our respondents). As the plot unfolds, heroes must show their courage and do their best to settle conflicts [23]. A 12-year-old boy, $\mathrm{MHEG}^{1}$, justified his preference for Negan claiming that "The series is more exciting with him".

Like witches in fairy tales, who awake psychic growth and happiness achievement in princesses and humble boys, the figure of a superhero is incomplete ${ }^{1}$ For privacy, only initials will be shown. 
without an antagonist. We cannot conceive a story of heroes and superheroes if there is no supervillain to fight with them. The role of the villain, also referred to as "antihero", is fundamental in movies following the postmodern trend in which villains themselves are the protagonists, without necessarily a hero in the narrative. The audience sometimes does not identify with villain protagonists but feels fascinated by their actions. This is the case of Rumpelstiltskin, Loki and Darth Vader. A 13-year-old boy (GVM) justified his preference for Darth Vader like that: “...though the story is about a villain, it is a gripping story and it is plausible..."

The antihero is characterized by being a charismatic and attractive character for the audience. According to our respondents:

Joker (preferred by our respondents) "is pretty naughty and funny... (CFO, 11-year-girl)"; "A character with a lot of attitude... (VFA, 12-year-old girl)";

"is funny and amuses himself doing what he does... (GP, 12-year-old boy)"

To our understanding, the antihero performs not in accordance with preestablished law, but with his/her own rules of law. According to a 13-year-old girl (LGPCG), "I like Joker because he is free, kind of insane and gutsy."; to a 13-year-old girl (MEGS), "Joker is very clever, does what he has to do, following his own sense of justice.", and to another 12-year-old girl (MEG), “Joker doesn't care about it all, is kind of crazy, he really doesn't care for anybody else."

In the post-classical movie narrative, there is a revival of the classical hero myth, which is to a certain extent modified: the villain presents a psychotic profile, but heroes often do too. Mainly children and adolescents no longer believe in the image of the persuasive hero. For them, the hero represents a "weak" character. Undoubtedly, young audiences firmly believe in the wicked character, in evil for the sake of evil, in psychopathy. A 12-year-old girl (LFWBOS) said that Joker “...is a real psychopath!", and a 12-year-old boy (APR) replied that Thanos "...has got a purpose for being a villain, he works towards goals..."

What is that fascination for evil all about? Means of communication and interactive media clearly expose horror, violence, and all kinds of abuse. The use of body and sexuality as aggressive instruments, the banalization of death and incest, for instance, are forms of communication that triumph over universal symbols of mutual respect and dignity. Violence is deliberately exposed in postclassical movies, nothing is considered grotesque; all forms of corruption, prejudice and human maladies are widely exploited [24] [25].

Post-modernity has completely replaced the classical form of narrative for new forms that have gained popularity among audiences. These narratives have become increasingly effective tools for the promotion of total demystification of the Western society, and preteens are the most affected ones since they are undergoing the process of identity construction and in search of meaningful models.

Epic genres and superhero movies have reached their height over the last 15 years. Great productions of this genre, like Harry Potter and The Lord of the Rings, and more recently The Avengers, have become even more popular among 
the age group surveyed in our study. In this context, post-classical villains belong to three main film and television genres/subgenres: psychological horror, disaster, war and political fiction.

To study the notion of leadership, it is necessary to address theories about the functioning of society, since the behavior of people is subjected to different influences according to the type of social relationship they develop. For example, people behave in qualitatively different ways in a small group where there is a leader. Leadership is a social relationship whose central element implies that someone must be accepted as a leader by a group of followers. A 12-year-old boy (NRH) justified his preference for Voldemort like this: “...as the wizard of all times, he is powerful and dangerous, but clever, has followers and dementors..."

For Weber [26], people obey because they are subordinated to certain legitimate forms of domination. Thanos, for example, the second most chosen character by respondents, has strength and power. Domination is not the mere exercise of power, not the simple imposition of one's own will over a social group, but the guarantee of obedience from a group of related people. Obedience is transformed into adherence thanks to legitimacy, which does not necessarily lead to force and/or threat, except in rare cases. Domination can be legitimized by different sources. For example, Thanos was described by two respondents like this: "Because he is very strong, tall, and has powers... (RCR, 12-year-old boy)"; "...Because he is the greatest and strongest Marvel villain... (JVEM, 11-year-old boy)"

Still according to Weber [26], there are three types of legitimate domination: traditional, legal or rational and charismatic. Traditional is the type of authority where obedience is connected to custom, to sanctity or to dignity established by orders and dominant agents. There is no formal, universal and objective right, but the one that governs relationships among people: tradition, and out it, norms are totally informal, private and subjected to the description of the individual. Examples of traditional authority include patriarchalism and feudalism.

The second type of authority is legal or rational, where obedience is governed by laws and regulations which can be legally created, modified and sanctioned. Examples of legal authority include bureaucracy, the armed and police forces.

Finally, the third type of authority is charismatic which is closely connected with our study. For Weber [26], in this type of domination, obedience to a person relies on his/her supernatural abilities, magical powers, revelations, heroism, intellectual power or eloquence. Due to his/her exceptional qualities, the political leader is worshipped.

Now, considering Joker, as the favorite character among respondents, he falls under the third type of authority: charismatic. Although Joker has become part of the collective unconscious of fans of comic books and Tim Burton's film Batman (1989), his popularity reached its peak in 2008, when he appeared in the movie The Knight of the Dark, by Christopher Nolan. As usual, the film deals with the endless battle between good and evil, but if we observe the essence of 
the narrative, it would be about the battle between heaven and hell, with the arrival of anti-Christ. According to the creation myth, the devil comes to earth to eliminate whoever crosses his way, to inflict an everlasting punishment on mankind. This argument is central in movies like Thor. Ragnorok and especially Batman, where Joker personifies this kind of villain. The personification becomes psychotic and it clearly reveals an insane obsession for Batman. This idea was reflected in the way a 12-year-old boy (HELS) justified his choice: “...He’s not only a villain, but also the evil, and Batman cannot exist without him..."

The villain's fixation on the hero is usually exaggerated, whether the reason is personal or circumstantial, the hero is invariably persecuted by the villain until the final battle. From its beginning, the journey of the hero and the villain is designed for that purpose [27]. Today's hero and antihero box-office smashes can have a connection with society's need to witness the defeat of a great villain (who symbolically can be associated with some political dictator or tyrant), usually representing a superior evil and destroyer of human values and morality.

The hero defeating the villain functions as the redemption of mankind's sins, making humans more human [28]. Despite the obsession for the villain, his magical powers or ancestors, or his psychopathic personality, he is always defeated by the hero in all these films. This is because, in the end, narratives recover the classical hero myth where the hero defeats the villain, by sheer luck or by divine protection. The villain, who is often well-built at the beginning of the narrative, usually assumes his/her basic characteristics throughout the movie, except in exceptional cases, such as Voldemort, who is a strong character, not only pure evil. Villains, however, are eventually expected to be evil characters.

According to Weber [26], on some historical occasions, social/political domination has been based on a certain personality, leadership and domination have always been intertwined and are not manifested in an exclusively unilateral way. A person can really be superior to other individuals, but he/she will become a leader unless others acknowledge or legitimize his/her outstanding qualities, only then, he/she will be followed and obeyed. The personality of a leader can be important, but that is not enough. Many people have a striking personality that could be referred to as leadership, but their actions have no impact on the world they live in, neither on their group of friends. Causing impact is fundamental, as a 13-year-old boy (LANL) justified his preference for Joker. “...He’s quite cool, he amuses the audience, his laughter is macabre, his makeup is awesome..."

For psychological science, personality is crucial because it creates a series of regular patterns in the way people behave, in the way they perceive reality, in the way they express their feelings and how they relate with others. But for political science, these elements are not enough. Political behavior is better explained by the characteristics of society, and by the relationships or situations it generates, rather than by people as individuals. It is worth mentioning that leadership depends on macro-factors that influence or determine them, as well as on how today's youth will choose their political leaders and project their notions of civility. 
According to Díaz [29], to deeply understand leadership, it should be considered as a matter of degree, distributed at different levels throughout the social system. Leadership would then be a social function and not only a quality of the individual. His/her motivations, intentions or actions do not matter, what really matters are the structures that determine them. If the foundations of social development are in the structures of society, the idea of the individual as a rational agent capable of making his/her own decisions is destroyed. Leaders would then be the result of historical development, pursuing goals conceived by society. If institutions are normative agendas that create common values and constitute a guideline for individuals' actions, leadership is a central political institution.

We now address the psychological foundations of leadership, drawing on Freud's ideas [30] that individual psychology is, at the same time, social psychology. By understanding the individual's psychic apparatus and its functioning, it is possible to track down and understand the underlying psychological factors throughout the social organization, from where the concept of "the mass" emerges and, in its turn, plays a decisive role in people's life.

When an individual is part of the mass, he/she renounces his/her own characteristics and suppresses his/her peculiarities, unconsciously acting as members of the mass, which imposes a uniform trait on them. According to Freud [30], by joining the mass, the individual is subjected to conditions that allow him/her to curb the representations of his/her unconscious impulses. The relationship between these psychological factors and political leaders is that the psychology of the masses allows understanding the mechanisms through which leaders have attempted to make individuals submissive and adherent to certain causes throughout the history of mankind. The phenomenon of suggestion caused by leaders conceals affection bonds, which constitute the essence of the masses and which allow psychological cohesion within them.

In the long run, leadership is related to power: A leader is a person who can change the facts. Nobody becomes a leader just by having subordinates, but by having his/her leadership legitimized by his/her followers. The leader and his followers are related through reciprocal influence; leadership is perceived as a transactional relationship, a sort of give-and-take relationship that influences and directs the actions of followers, whether they are faithful-those who are committed for reasons of moral character, or mercenaries-those who only commit themselves for self-interest. Regardless of the case, the relationship between leader and followers is vital for any relationship of leadership.

And at this point, we establish the relationship with civic engagement from the idea of civic skills, which are required in the participation of political and civic life and which we take to the field of education. There is great interest in civic engagement in the literature on human development, with regard to youth development, as civic skills go beyond political practice, extending between dialogue, interpersonal perspective and critical thinking, aspects that appear consistently in the profiles of anti-hero characters. 
"Beyond our families, we have friends, neighbors, fellow citizens in the communities where we reside. What does it mean to be a good friend, a good neighbor, or a good citizen? The answer is the same in all cases: service and engagement $(. .$.$) a very definition of community in sociological$ terms is a group of people who feel reciprocal obligation to one another [31]."

\section{Final Remarks}

The personal qualities of a leader are, in part, product of the environment, of his/her family, even of the country where he/she lives in. This study has confirmed what other authors [32] [33] [34] [35] had already warned: that more than never the qualities required for the development of a leader cannot be defined in an abstract way, it must be connected to the circumstances surrounding the emergence of such a leader.

Despite confirming studies already carried out, this article brings a differential that is the research problem itself: verifying the teenagers' conceptions from their own perception and symbolic projections, presented from the identifications with the "villain" characters of cinema and TV. This is an innovation in the way of thinking about the survey questionnaire.

Initially, we can still validate the hypotheses presented above, which confirm the research problem. It was verified what adolescents think about leadership and their projections and identifications are related to moral values such as dignity and respect and material values of power and goods. Not only is the identification with the characters on the agenda, but also certain doses of verisimilitude and internal coherence, both in the world that surrounds the hero, the villain and the political leader, as well as the cause that motivates them and the obstacles that present themselves to this cause, which always involves a certain nobility of principle. It is possible for an aspiring leader to inquire about the nature of Evil in order to understand it, but at some point he must be aware of the right path and follow it.

The projections the respondents of our study made relative to the television and movies characters presented were interrelated with three essential factors in terms of leadership and social context: a position within the social structure, opportunities available and historical determinants of each society.

As a prevalence study, the justifications of pre-teen respondents revealed a conception of leaders as those who can transform their environment, and who can make major changes in institutional structures; however, those structures precede and condition them, constituting their own conduct and limiting their capacity for action. In this sense, the institutional and social structure functions as a factor that truly corroborates the characteristics of leadership.

The exercise of leadership is also related to historical determinants in each society. The position someone holds is also an important factor, but it is not leadership per se, since top positions in government or in other types of organi- 
zation can be held by a bureaucrat or someone who shows no leadership in decision-making processes.

In this respect, holding a high institutional position or having power does not necessarily mean leadership. In fact, there are very powerful people who do not exert any leadership. The difference between the power of leaders and other types of power lies in the relationship leaders establish with other people. According to Blondel [36], a leader is someone who influences a group, even if he is not formally managing that group.

Thus, this study draws our attention to civism as a potentiality of virtues or attitudes that can transform the individual into a good citizen or a good democrat, and who is closely connected to education. Teaching civism is teaching ethics. Civism is transmitted not by theories or norms of conduct, but by providing a civic model, by creating an atmosphere that leads to civic attitudes, which, in turn, implies rejecting a society that fosters a comfortable and easy life, glory, power and personal success at any cost. Teaching civism, as the most basic aspect of education, stimulating values of responsibility, solidarity and tolerance, is vital and necessary for leaders and communities.

\section{Acknowledgements}

The author would like to thank: Dr. Adauri Brezolin, who translated the article into English; Lucian da Silva Barros, for contributions in discussing characters' profiles, and the school "Colégio Objetivo da Praia Grande-Brasil".

\section{Conflicts of Interest}

The author declares no conflicts of interest.

\section{References}

[1] Gardner, J.W. (1993) On Leadership. Free Press, New York. https://books.google.com.br/books?id=NxXGFwDhLicC\&dq=gardner+1993+politic al+leader\&lr $=\& h l=p t-B R \&$ source $=$ gbs_navlinks_s

[2] Aristóteles (1997) La política. Alianza, Madrid.

[3] Camps, V. (1990) Virtudes públicas. Espassa, Madrid.

[4] Ehrlich, T. (2000) Civic Responsibility and Higher Education. Oryx, Phoenix.

[5] Piaget, J. (1994) O juízo moral na criança. Summus Editorial, São Paulo.

[6] Kohlberg, L. (1984) The Psychology of Moral Development. Harper and Row, San Francisco.

[7] Lucas, G. (1977) Star Wars [DVD]. USA: 20th Century Fox. 121 Min.

[8] Singer, B. (2016) X-Men Apocalypse [DVD]. USA: Marvel Entertainment/20th Century Fox. 144 Min.

[9] Gunn, J. (2014) Guardians of the Galaxy [DVD]. USA: Marvel Studios/Walt Disney Studios Motion Pictures. 122 Min.

[10] Russo, A. and Russo, J. (2018) Avengers: Infinity War [DVD]. USA: Marvel Studios/Walt Disney Studios Motion Pictures. 149 Min. 
[11] Whedom, J. (2012) The Avengers [DVD]. USA: Marvel Studios/Paramount Pictures/Walt Disney Studios Motion Pictures. 144 Min.

[12] Snyder, Z. (2016) Batman v Superman: Dawn of Justice [DVD]. USA: DC Entertainment/Warner Bros. Pictures. 151 Min.

[13] Nolan, C. (2008) The Dark Knight [DVD]. USA: DC Comics/Warner Bros. Pictures. $152 \mathrm{Min}$.

[14] Darabond, F. and Kirkman, R. (2010-2019) The Walking Dead [TV Serie]. USA: AMC Studios. 42/60 Min.

[15] Horowitz, A. and Kitsis, E. (2011-2018) Once upon a Time [TV Serie]. USA: Disney TV/ABC Studios. 43 Min.

[16] Benioff, D. and Weiss, D.B. (2011-2018) Game of Thrones [TV Serie]. USA: WarnerBros. Television Distribuition. 50/80 Min.

[17] Yates, D. (2010) Harry Potter and the Deathly Hallows-Part 1 [DVD]. United Kingdom/USA: Heyday Films/Warner Bros. Pictures. 146 Min.

[18] Yates, D. (2011). Harry Potter and the Deathly Hallows-Part 2 [DVD]. United Kingdom/USA: Heyday Films/Warner Bros. Pictures. 130 Min.

[19] Oxford English Dictionary (2020). http://www.oed.com

[20] Calvez, J.-Y. (1969) Introducción a la vida política. Estela, Barcelona.

[21] Gonzalez Requena, J. (2012) Clásico, maneirismo y postclásico. Los modos del relato en el cine de Hollywood. Castilla Ediciones, Valladolid.

[22] Sánchez Casarrubios, M. (2012) Narración y sociedade: El villano en el cine contemporâneo (2000-2010). Revista Aequitas, 2, 36.

http://revistaaequitas.wordpress.com/2012/08/08/numero-2-2012-2

[23] Savater, F. (1982) La tarea del héroe. Taurus, Madrid.

[24] La Taille, Y. (2008) Formação ética. Do tédio ao respeito de si. ArtMed, Porto Alegre.

[25] Bauman, Z. and Donskis, L. (2014) Cegueira Moral: A perda da sensibilidade na modernidade líquida. Zahar editora, Rio de Janeiro.

[26] Weber, M. (1996) Economia y sociedade. FCE, México.

[27] Campbell, J. (2020) O herói de mil faces. Cultrix/Pensamento, Rio de Janeiro. https://projetophronesis.files.wordpress.com/2009/08/joseph-campbell-o-heroi-demil-faces-rev.pdf

[28] Eco, U. and Chilton, N. (1972) The Myth of Superman. Diacritics, 2, 14-22. https://doi.org/10.2307/464920

[29] Díaz, J.F.J. (2008) Enfoque sociologico para el studio del liderazgo político. Revista Castellano-Manchega de Ciencias Sociales, 9, 189-203. https://doi.org/10.20932/barataria.v0i9.186

[30] Freud, S. (2001) Psicología de las masas y análisis del Yo. Amorrortu, Buenos Aires.

[31] Damon, W. (2003) Noble Purpose: The Joy of Living a Meaningful Life. Templeton Foundation Press, Philadelphia.

[32] Colby, A., Beaumont, E., Ehrlich, T. and Corngold, J. (2007) Educating for Democracy: Preparing Undergraduates for Responsible Political Engagement. Jossey-Bass, San Francisco.

[33] Colby, A., Ehrlich, T., Beaumont, E. and Stephens, J. (2003) Educating Citizens. JosseyBass, San Francisco. 
[34] Crocetti, E., Jahromi, P. and Meeus, W. (2012) Identity and Civic Engagement in Adolescence. Journal of Adolescence, 35, 521-532. https://doi.org/10.1016/j.adolescence.2011.08.003

[35] Yates, M. and Youniss, J. (1999) Roots of Civic Identity: International Perspectives on Community Service and Activism in Youth. Cambridge University Press, New York. https://doi.org/10.1017/CBO9780511751820

[36] Blondel, J. (1987) Political Leadership. Towards a General Analysis. Sage, Londres. 